\title{
IDENTIFIKASI MORFOLOGI BENIH PADI SAWAH VARIETAS PANDANWANGI DI LIMA LOKAS KECAMATAN
}

\author{
Oleh: \\ Angga Adriana Imansyah*) \\ Frilynthia Dwi Ayu Andreyuni**)
}

\begin{abstract}
Abstrak
Pandanwangi merupakan padi varietas lokal di Kabupaten Cianjur, namun tidak semua wilayah di Kabupaten Cianjur dapat ditanami padi Pandanwangi dengan ciri khas tertentu, oleh karena itu untuk menanam padi Pandanwangi diperlukan persyaratan topografi yang spesifik tanpa menghilangkan karater dan kualitas benih padi Pandanwangi. Penelitian dilakukan di Laboratorium Vocational Education Development Centre and Agriculture (VEDCA) Cianjur pada bulan Februari sampai Maret 2018. Penelitian ini bertujuan untuk menentukan karakteristik morfologi benih pada lima lokasi yaitu Kecamatan Warungkondang, Cugenang, Mande, Cianjur, Campaka serta membandingkan identifikasi morfologi benih dengan hasil deskripsi umum morfologi benih padi Pandanwangi. Rancangan yang digunakan untuk data kuantitas menggunakan Rancangan Acak Lengkap (RAK) non faktorial dengan 5 perlakuan dan 5 ulangan. Masing-masing perlakuan yaitu benih padi Pandanwangi yang berlokasi A (Warungkondang), B (Cugenang), C (Cianjur), D (Campaka) dan E (Mande). Parameter yang diamati meliputi benih murni, benih tanaman lain, kotoran benih dan bobot 1000 butir benih padi Pandanwangi, sedangkan untuk data kualitas yaitu identifikasi morfologi benih di lima lokasi Kecamatan menggunakan analisis deskripsi lalu dibandingkan dengan deskripsi umum morfologi benih padi Pandanwangi. Hasil penelitian menunjukkan bahwa identifikasi morfologi benih di lima lokasi Kecamatan yang terbaik pada perlakuan di lokasi Kecamatan Warungkondang, namun Kecamatan Cugenang, Kecamatan Cianjur dan Campaka lebih baik dibanding Kecamatan Mande.
\end{abstract}

Kata Kunci: Morfologi benih, topografi, benih Padi Pandanwangi.

\section{Abstract}

Pandanwangi is a local varieties of rice in Cianjur regency, but not all areas in Cianjur regency can be planted with certain characteristics of Pandanwangi rice, therefore to grow rice Pandanwangi required specific topographic requirements without removing the character and quality of Pandanwangi rice seeds. The research was conducted at Cianjur Vocational Education Development and Agriculture Laboratory (VEDCA) Cianjur from February to March 2018. The objective of this research was to determine the morphological characteristics of the seeds in five locations, namely Warungkondang, Cugenang, Mande, Cianjur, Campaka and compare the morphological identification of seeds with the results General description of Pandanwangi rice seed morphology. The design used for quantity data using non-factorial Randomized Design (RAK) with 5 treatments and 5 replications. Each treatment is Pandanwangi rice seed located $A$ (Warungkondang), $B$ (Cugenang), C (Cianjur), D (Campaka) and E (Mande). The parameters observed were pure seed, seed of other plants, seed manure and weight of 1000 seeds of Pandanwangi rice seeds, while for the quality data that is the identification of seed morphology in five locations of sub district using description analysis then compared with common description of Pandanwangi rice seed morphology. The results showed that the morphological identification of seeds in five sub-district locations was the best in the treatment at Warungkondang subdistrict, but Cugenang sub-district, Cianjur and Campaka sub-districts were better than Mande sub-district.

Keywords: Seed morphology, topography, Rice seed Pandanwangi.

*) Dosen Fakultas Sains Terapan UNSUR

**) Alumni Fakultas Sains Terapan UNSUR 


\section{PENDAHULUAN}

Pandanwangi merupakan varietas yang dapat tumbuh dan berkembang menjadi varietas lokal di Kabupaten Cianjur. Namun tidak semua wilayah di Kabupaten Cianjur dapat ditanami padi Pandanwangi dengan ciri khas tertentu, oleh karena itu untuk menanam padi Pandanwangi diperlukan persyaratan topografi yang spesifik. Wilayah yang sesuai dengan persyaratan penanaman padi Pandanwangi ada di tujuh Kecamatan Cianjur, yaitu di Kecamatan Warungkondang, Kecamatan Gekbrong, Cugenang, Cianjur, Campaka, Cibeber dan Cilaku. Tujuh Kecamatan di Cianjur tersebut dapat menghasilkan beras Pandanwangi yang membawa karakteristik disetiap lokasinya dan empat dari tujuh Kecamatan memiliki sentra produksi yang lebih tinggi yaitu pada Kecamatan Warungkondang, Cugenang, Cianjur dan Campaka (MP3C, 2015). Sedangkan untuk Kecamatan Mande adalah Kecamatan yang tidak termasuk kedalam Indikasi Geografis Penanam Padi Pandanwangi.

Menurut ISTA (2006) benih bermutu adalah benih yang dapat mencerminkan karakteristik varietasnya. Karakteristik benih yang bermutu dapat dideskripsikan sesuai dengan varietas benar yang memiliki mutu genetis, fisiologis dan fisik yang baik, dengan melalui pengujian benih.

Untuk mengetahui karakteristik dapat dibuktikan dengan identifikasi morfologi benih salah satunya dengan pengujian deskripsi hidup benih unggul yang bermutu tinggi, setiap benih memiliki karekteristik yang dapat dikenali, walaupun dalam satu varietas dapat ditanam diberbagai lokasi (BPMBTPH, 2004).

Faktor pengujian kualitas benih ini akan dibandingkan dengan karakter morfologi benih untuk mengetahui kualitas varietas benih yang dapat ditanam diberbagai lokasi sesuai topografi yang berpengaruh terhadap kualitas benih dan dapat menunjukan karakteristik benih. Berdasarkan adanya hubungan antara identifikasi morfologi dan produktivitas benih, maka timbul gagasan untuk menciptakan suatu tipe benih yang ideal (ideotype) sesuai dengan deksripsi umum dan lokasi tanam yang sesuai dengan varietas padi Pandanwangi serta kualitas benih yang dihasilkannya tetap terjaga.

Tujuan penelitian ini adalah menentukan karakteristik morfologi benih pada lima lokasi yaitu Kecamatan Warungkondang, Cugenang, Cianjur, Campaka, Mande dan membandingkan identifikasi morfologi benih dengan hasil deskripsi umum morfologi benih padi Pandanwangi.

\section{METODE PENELITIAN}

\section{Waktu dan Tempat Penelitian}

Penelitian dilaksanakan di Laboratorium VEDCA (Vocational Education Development Centre and Agriculture) Cianjur dan dilaksanakan bulan Februari sampai Maret 2018.

\section{Alat dan Bahan}

Alat yang digunakan dalam penelitian yaitu magnifying lamp, soil divider, kantong plastik, meja analisis kemurnian, timbangan analitik, cawan petri, bandcounter, pinset, mikroskop, label dan alat tulis. Bahan yang digunakan dalam penelitian yaitu sampel benih padi varietas Pandanwangi dari lima kecamatan yang berlokasi di Warungkondang, Cugenang, Cianjur, Campaka dan Mande secara acak dengan berat masing-masing 70 gram setiap benih per lokasi (ISTA, 2006).

\section{Metode Penelitian}

Metode penelitian yaitu dengan (1) Pengambilan sampel benih dan beras dari lima lokasi Kecamatan yang berbeda. (2) Menimbang sampel benih setiap lokasi dengan berat 70 gr diambil secara acak setiap lokasi, untuk pengujian kemurnian benih dan penetapan bobot 1000 butir sebagai data kuantitatif dan identifikasi morfologi benih sebagai data kualitatif. (3) Observasi tentang topografi di setiap lima lokasi kecamatan yang berlokasi di 
Warungkondang, Cianjur, Cugenang, Mande dan Campaka sebagai data kualitatif.

\section{Rancangan Penelitian}

Rancangan

penelitian

menggunakan Racangan Acak Kelompok (RAK) non factorial untuk data kuantitatif, setiap pengukuran parameter dilakukan lima perlakuan dan lima kali ulangan. Perlakuan yang diuji yaitu tiap daerah topografi Warungkondang, Cugenang, Cianjur, Campaka dan Mande.

Teknik pengumpulan data yaitu dengan Menghitung persentase pengujian kemurnian benih dengan satuan gram dengan rumus:

$$
\begin{aligned}
\% B M & =\frac{B M}{(B M+B T L+K B)} X 100 \% \\
\% B T L & =\frac{B T L}{(B M+B T L+K B)} X 100 \% \\
\% K B & =\frac{K B}{(B M+B T L+K B)} X 100 \%
\end{aligned}
$$

Jika kehilangan maksimal 5\% maka dihitung menggunakan rumus faktor kehilangan yaitu:
$\frac{C K-(B M+B T L+K B)}{C K} X 100 \% \leq 5 \%$

keterangan: $\mathrm{BM}=$ Benih Murni, BTL = Benih Tanaman Lain, $\mathrm{KB}=$ Kotoran Benih dan CK = Contoh Kerja (ISTA, 2006).

Menghitung variance (ragam), standar deviasi untuk penetapan berat 1000 butir benih setiap lokasi Kecamatan dengan menggunakan rumus:

$$
\mathbf{V}=\frac{\mathbf{n} \sum \mathbf{x}^{2}-\left(\sum \mathbf{x}\right)^{2}}{\mathbf{n}(\mathbf{n}-\mathbf{1})}
$$

Keterangan: $\mathrm{V}=$ Variance (ragam), $\mathrm{x}=$ Berat masing-masing ulangan (dalam gram), $\mathrm{n}=$ Jumlah ulangan

$$
\mathbf{S}=\sqrt{ } \mathbf{V}
$$

Keterangan: $\mathrm{S}=$ Standar deviasi dan $\mathrm{V}=$ Varians

$$
\text { Koefisien Variasi }=\frac{S}{\mathrm{x}} x 100
$$

Keterangan: $\mathrm{x}=$ Berat rata-rata 100 butir (ISTA, 2006).

Membandingkan Identifikasi morfologi benih dengan deskripsi benih Pandanwangi secara umum:

Tabel 1. Deskripsi umum morfologi benih padi sawah varietas Pandanwangi.

\begin{tabular}{|ccc|}
\hline No & Indikator & Parameter \\
\hline 1 & Bulu pada gabah & Berbulu penuh \\
2 & Ukuran bulu gabah & Panjang \\
3 & Warna ujung gabah & Warna jerami \\
4 & Warna sterilima & Tidak berwarna \\
5 & Warna gabah & Kuning emas \\
6 & Bentuk gabah & Bulat agak panjang \\
7 & Tipe endosperm & Berperut \\
8 & Aroma beras & Beraroma Pandan \\
\hline
\end{tabular}

Sumber : Balai Besar Penelitian Padi, 2004.

\section{Jenis dan Sumber Data}

Jenis dan sumber data yang digunakan dalam penelitian ini adalah Data Kuantitatif yaitu hasil pengukuran dalam pengujian kualiatas benih dengan menghitung persentase kemurnian benih, serta penetapan berat 1000 butir dan Data Kualitatif yaitu hasil observasi dan wawancara ke setiap lokasi kecamatan tentang kondisi topografi, lalu mendeskripsikan fakta dan fenomana yang diamati dengan membandingkan hasil identifikasi morfologi benih Pandanwangi setiap lokasi Kecamatan, yang dapat mencerminkan kualitas mutu benih dan beras tersebut.

\section{Teknik Analisis Data}

Teknik analisis data yaitu analisi deksripsi digunakan untuk mendeskriptifkan karakteristik morfologi benih Pandanwangi di lima Kecamatan, yang dibantu dengan pengujian kualitas benih dan beras di lima Kecamatan tersebut sesuai skala laboratorium.

\section{Pengujian Hipotesis}

Pengujian hipotesis untuk data kuantitatif yang diperoleh dianalisa dengan uji Analisis Sidik Ragam atau 
ANOVA (Analysis of V ariance), kemudian untuk perlakuan yang berpengaruh akan uji lanjut DMRT (Duncan Mutiple Range Test) dengan taraf $5 \%$ sedangkan untuk data kualitatif dianalisa dengan metode deskriptif, dengan menggunakan minitab dan SPSS, lalu data kuantitatif dan kualitatif dibandingkan untuk mengetahui apakah topografi berpengaruh nyata terhadap morfologi benih padi Pandanwangi tiap wilayah yang ditanam.

\section{HASIL DAN PEMBAHASAN}

\section{Data Sejarah benih di lima lokasi Kecamatan}

Sebelum melakukan pengujian kemurnian benih dan penetapan bobot 1000 butir benih serta identifikasi morfologi benih Padi Pandanwangi dari setiap lokasi, perlu dilakukannya observasi tentang sejarah benih. Dilihat pada tabel 2.

Tabel 2. Data musim tanam, tanggal panen dan tanggal benih padi Pandanwangi masuk ke laboraturium setiap lokasi Kecamatan.

\begin{tabular}{llccc}
\hline No & Lokasi & $\begin{array}{c}\text { Musim } \\
\text { Tanam }\end{array}$ & $\begin{array}{c}\text { Tanggal } \\
\text { Penen }\end{array}$ & $\begin{array}{c}\text { Tanggal Masuk } \\
\text { Ke }\end{array}$ \\
\hline 1 & Warungkondang & 2017 & 11 Juni 2017 & \\
2 & Cugenang & 2017 & 21 Juni 2017 & \\
3 & Cianjur & 2017 & 27 Juni 2017 & 14 Februari 2018 \\
4 & Campaka & 2017 & 10 Juni 2017 & \\
5 & Mande & 2017 & 30 Juni 2017 & \\
\hline
\end{tabular}

Data sejarah benih di lima lokasi kecamatan berbeda, karena musim panen yang berbeda, perbedaan itu karena lokasi dan pengaruh lingkungan yang berbeda, seperti paparan sinar yang berbeda di setiap lokasi yang dapat memberi dampak cepat atau terhambatnya pertumbuhan untuk siap panen. Hal itu dapat mempengaruhi hasil uji kemurnian dan penetapan bobot 1000 butir benih padi Pandanwangi. Dilihat dari musim tanam dan tanggal panen perlu diketahui agar kualitas benih tidak rusak dan dapat dijadikan pembanding dengan deskripsi umum benih padi Pandanwangi (BPMBTPH, 2004).

\section{Hasil uji anova kemurnian benih dan bobot 1000 butir}

Tabel 3. Hasil ANOVA benih murni dalam pengujian kemurnian benih padi Pandanwangi di lima lokasi Kecamatan.

\begin{tabular}{lrrrrr}
\hline \multicolumn{1}{c}{ Source } & \multicolumn{1}{c}{ DF } & \multicolumn{1}{c}{ SS } & \multicolumn{1}{c}{ MS } & \multicolumn{1}{c}{ F } & \multicolumn{1}{c}{ P } \\
\hline Perlakuan & 4 & 87,9511 & 21,9878 & 25399,45 & 0,000 \\
Kelompok & 4 & 0,0063 & 0,0016 & 1,82 & 0,174 \\
Error & 16 & 0,0139 & 0,0009 & & \\
Total & 24 & 87,9712 & & & \\
\hline
\end{tabular}

Tabel 4. Hasil ANOVA kotoran benih murni dalam pengujian kemurnian benih padi Pandanwangi di lima lokasi Kecamatan.

\begin{tabular}{lrrrrr}
\hline \multicolumn{1}{c}{ Source } & DF & \multicolumn{1}{c}{ SS } & \multicolumn{1}{c}{ MS } & \multicolumn{1}{c}{ F } & P \\
\hline Perlakuan & 4 & 63,6911 & 15,9228 & 6053483,49 & 0,0000 \\
Kelompok & 4 & 0,0001 & 0,0000 & 10,90 & 0,0000 \\
Error & 16 & 0,0000 & 0,0000 & & \\
Total & 24 & 63,6913 & & & \\
\hline
\end{tabular}

Tabel 4. Hasil ANOVA penetapan bobot 1000 butir benih padi Pandanwangi di lima lokasi Kecamatan.

\begin{tabular}{lrrrrr}
\multicolumn{1}{r}{ Source } & DF & \multicolumn{1}{c}{ SS } & MS & \multicolumn{1}{c}{ F } & \multicolumn{1}{c}{ P } \\
\hline Perlakuan & 4 & 1,28960 & 0,322401 & 28,78 & 0,000 \\
Kelompok & 4 & 0,00016 & 0,000040 & 0,00 & 1,000 \\
Error & 191 & 2,13983 & 0,011203 & & \\
Total & 199 & 3,42960 & & & \\
\hline
\end{tabular}


Dari tabel 3, 4 dan 5 pengujian kemurnian benih dengan parameter benih murni dan kotoran benih serta pengujian penetapan bobot 1000 butir terhadap lima perlakuan topografi terlihat signifikan, karena $\mathrm{P}$ value lebih kecil dari $\alpha 0.05$, sehingga topografi berpengaruh terhadap pengujian kemurnian benih dan bobot 1000 butir. Maka perlu dilakukan uji beda nyata dengan menggunakan uji lanjut DMRT.

\section{Pengujian Kemurnian Benih Padi Pandanwangi}

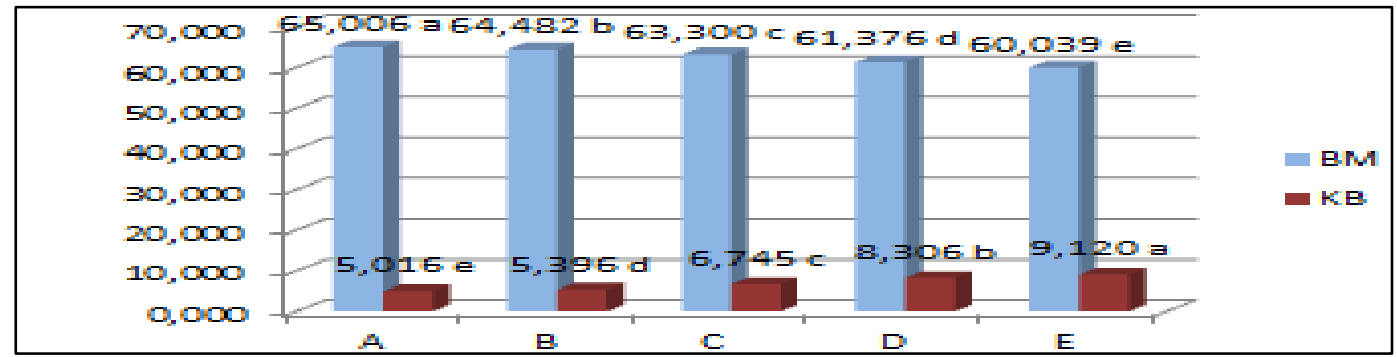

Gambar 1. Histogram uji DMRT kemurnian benih padi pandanwangi di lima lokasi kecamatan.

Keterangan: A (Kec.Warungkondang) B (Kec. Cugenang) C (Kec Cianjur) D (Kec. Campaka) E (Kec. Mande).

Dari uji lanjut DMRT pada taraf signifikansi 5\%, dalam kemurnian benih dengan prameter benih murni dan kotoran benih padi Pandanwangi di lima lokasi Kecamatan, menunjukkan perlakuan antar topografi berbeda nyata terhadap perlakuan topografi lainnya. Dengan 5 kali ulangan benih murni dan kotoran benih padi Pandanwangi yang terbaik ada di perlakuan topografi A (Kecamatan Warungkondang) dengan jumlah benih murni 65,006 gram dan kotoran benih 5,016 gram, sedangkan topografi E (Kecamatan Mande) memiliki berat benih murni sebesar 60,059 gram dan kotoran benih sebesar 9,120 gram padi Pandawangi yang terendah, dibandingkan Kecamatan Cugenang (BM $=64,482$ gram dan $\mathrm{KB}=5,396$ gram), Kecamatan Cianjur $(B M=63,300$ gram dan $\mathrm{KB}=6,745$ gram) dan Kecamatan Campaka (BM = 61,376 gram dan $\mathrm{KB}=$ 8,306 gram). Hal ini disebabkan suhu di topografi A $\left(20^{\circ}-29^{\circ} \mathrm{C}\right.$ dengan ketinggian tempat $650 \mathrm{~m} \mathrm{dpl}), \mathrm{B}\left(19^{\circ}-25^{\circ} \mathrm{C}\right.$ dengan ketinggian tempat $680 \mathrm{~m} \mathrm{dpl}), \mathrm{C}\left(20^{\circ}-30^{\circ}\right.$ $\mathrm{C}$ dengan ketinggian tempat $500 \mathrm{~m} \mathrm{dpl}$ ) dan D $\left(18^{0}-25^{\circ} \mathrm{C}\right.$ dengan ketinggian tempat $690 \mathrm{~m} \mathrm{dpl}$ ) memiliki suhu dan ketinggian tempat yang memenuhi suhu optimal untuk kriteria tanaman padi Pandanwangi yaitu $25^{\circ} \mathrm{C}$ hingga $30^{\circ}$. Menurut (MP3C, 2015) padi Pandanwangi sangat sesuai tumbuh pada areal persawahan dengan suhu udara $25{ }^{\circ} \mathrm{C}$ hingga $30{ }^{\circ} \mathrm{C}$ dengan ketinggian $450-800$ m dpl.

Berbeda halnya dengan topografi E (Kecamatan Mande) yang memiliki suhu $23{ }^{\circ} \mathrm{C}$ hingga $32{ }^{\circ} \mathrm{C}$ dan ketinggian tempat $336 \mathrm{~m}$ dpl yang bertaraf memberikan cekaman terhadap tanaman padi Pandanwangi. Cekaman suhu tinggi dapat mengkibatkan penurunan kualitas benih, karena kotoran benih berupa benih hampa Pandanwangi di lokasi Kecamatan Mande paling banyak ditemui. Hal ini didukung oleh penelitian yang menunjukkan hasil bahwa gangguan suhu tinggi dapat meningkatkan persentase bunga steril yang mengakibatkan menurunnya jumlah serbuk sari yang ditangkap oleh stigma, sehingga berdampak pada peningkatan jumlah persentase benih hampa (Nagai and Makino, 2009). Berbeda hal nya jika terjadi cekaman suhu rendah dapat mengakibatkan: 1) penghambatan tumbuh yaitu keterlambatan pembentukan malai, 2) malai steril yaitu berkurangnya hasil karena malai hampa akibat cekaman suhu rendah selama fase pembentukan malai hingga pembungaan, 3) kombinasi keduanya (Toriyama, 1994).

Faktor lainnya yang menyebabkan topografi E memiliki benih murni dan 
kotoran benih yang rendah karena lamanya penyinaran yang dapat memberikan hasil yang berbeda dalam proses pengisian benih. Hal ini sesuai dengan penelitian (Wahyuni et al., 2004) yang menyatakan bulir benih yang terisi sempurna karena adanya penyinaran dengan ketinggian tempat yang memiliki suhu normal atau sesuai karakteristik tanaman.

Hama dan Penyakit yang menyerang di lima lokasi Kecamatan pun berbeda-beda. Hama yang dapat menyebabkan kemurnian benih tidak optimal adalah hama penggerek batang dan penyakit yang memperbanyak benih hampa Pandanwangi adalah tungro. Hama dan Penyakit pun berdampak terhadap kontaminan yang menyebabkan adanya benih tanaman lain, karena hama menjadi sarana penularan penyakit dan kontaminasi tanaman. Gejala hama dan penyakit tumbuh karena faktor lingkungan (abiotik), yang mendukung sebagai tempat perkembangan hidupnya dan berdampak terhadap abnormalitas hasil seperti ketidaksempurnaan hasil seperti benih (Agrios 2005).

\section{Penetapan Bobot 1000 Butir Benih Padi Pandawangi}

Tabel 6. Hasil penetapan bobot 1000 butir benih padi Pandanwangi di lima lokasi Kecamatan.

\begin{tabular}{|c|c|c|c|c|c|c|c|}
\hline \multirow[t]{2}{*}{ No } & \multirow[t]{2}{*}{ Lokasi } & \multicolumn{6}{|c|}{ Gram } \\
\hline & & $\mathbf{x}$ & $x^{2}=$ & $\mathbf{V}$ & SD & $\mathbf{K} \mathbf{V}$ & $\begin{array}{l}\text { Bobot } \\
\text { looo } \\
\text { butir }\end{array}$ \\
\hline 1 & Warungkondang & 23,832 & 71,133 & 0,019 & 0,137 & 4,599 & 29.7 \\
\hline 2 & Cugenang & 24,402 & 74,494 & 0,009 & 0.095 & 3.105 & 30,5 \\
\hline 3 & Cianjur & 24,175 & 73.085 & 0.005 & 0.067 & 2,230 & 30,2 \\
\hline 4 & Campaka & 23,418 & 68.569 & O,OO3 & 0,055 & 1.866 & 29,3 \\
\hline 5 & Mande & 22,582 & 63,918 & 0,025 & 0,157 & 5,579 & 28,2 \\
\hline
\end{tabular}

Keterangan: $\mathrm{X}=$ Total bobot 1000 butir, $\mathrm{X}^{2}=$ Total bobot 1000 butir yang telah dipangkatkan, $\mathrm{V}=$ Variance (Nilai Keragaman), SD $=$ Standar Deviasi, KV= Koefisien Varian.

Hasil menunjukkan bahwa penetapan bobot 1000 butir benih padi Pandanwangi yang terbaik dan sesuai dengan deskripsi umum benih padi Pandanwangi terletak pada Kecamatan Warungkondang dengan total 29,7 gram sedangkan bobot 1000 butir benih padi Pandanwangi di Kecamatan Campaka 29,2 gram dan Kecamatan Mande memiliki bobot 1000 butir benih padi Pandanwangi yang terendah dari lima Kecamatan yaitu dengan total 28,2 gram. Tinggi rendahnya suatu bobot 1000 butir dapat dipengaruhi oleh interaksi padi Pandanwangi dengan lingkungan lokasi tanam padi Pandanwangi, hal ini sesuai dengan penelitian (Wahyuni et al., 2004) densitas benih dipengaruhi oleh interaksi antara varietas dan kondisi lingkungan produksi, demikian pula bobot 1000 butir.

Topografi A memiliki ketinggian tempat $650 \mathrm{~m}$ dpl sedangkan Kecamatan Mande ketinggian tempat $336 \mathrm{~m}$ dpl, dengan perbedaan ketinggian tempat akan berbeda juga interaksi tanaman terhadap lingkungan, serta faktor pendukung berupa perlakuan yang diberikan berbeda seperti nutrisi berupa pupuk dan pestisida berbeda dalam sistem budidaya padi Pandanwangi, akan menghasilkan berat bobot 1000 butir yang berbeda tiap lokasi Kecamatan, hasil ini sejalan dengan penelitian Wahyuni and Nugraha (2005), bahwa perbedaan berat bobot 1000 butir bukan karena faktor lingkungan saja tetapi faktor perlakuan dalam sistem budidayanya.

Namun di lima kecamatan yang ditanam padi Pandanwangi yang memiliki bobot 1000 butir lebih tinggi yaitu pada Kecamatan Cugenang dengan total 30,5gram dan Kecamatan Cianjur 30,2 gram, karena kapasitas limbung (sink size) dalam hal ini ukuran benih, biasanya ditentukan sebelum tahap pembungaan, seperti jumlah malai per rumpun dan jumlah gabah per malai dan menurut Yoshida and Parao (1976), jumlah benih isi dan bobot 1000 butir ditentukan selama tahap pematangan atau setelah pembungaan. 


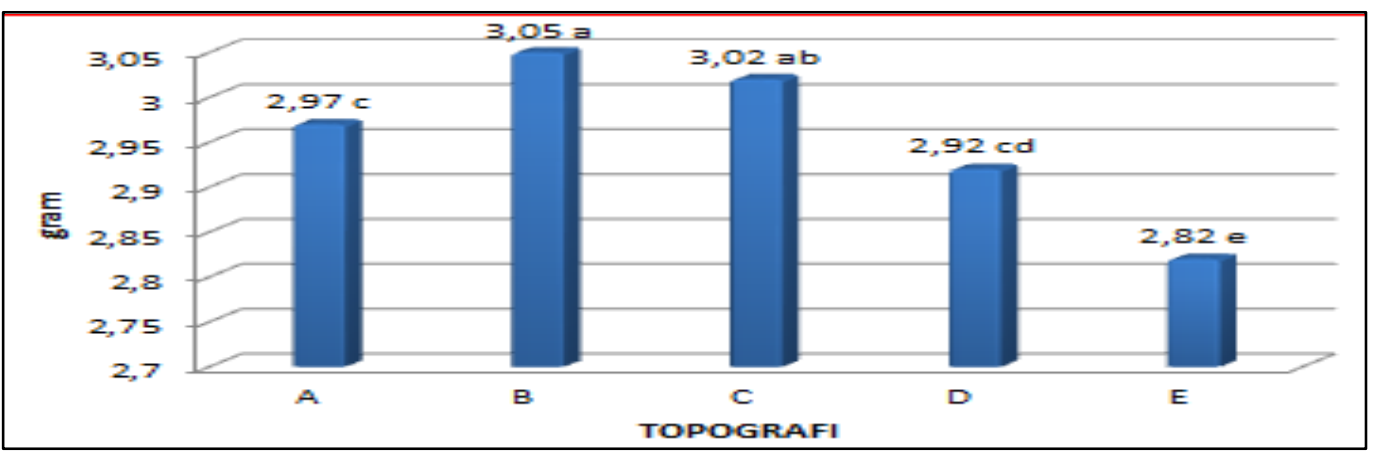

Gambar 2. Histogram uji DMRT bobot 1000 butir benih padi pandanwangi di lima lokasi kecamatan.

Keterangan: A (Kec.Warungkondang) B (Kec. Cugenang) C (Kec Cianjur) D (Kec. Campaka) E (Kec. Mande).

Dari uji lanjut DMRT pada taraf signifikansi $\propto$ 0.05, dalam penetapan bobot 1000 butir benih padi Pandanwangi di lima lokasi, menunjukkan jika perlakuan topografi E (Kecamatan Mande) sebesar 28,2 gram berbeda nyata dengan ke empat topografi lainya. Karena topografi yang tidak sesuai dengan kriteria padi Pandanwangi dan cuaca yang tidak optimal selama tahap pembelahan dan antesis serta kerapatan tanaman yang tinggi menentukan jumlah gabah isi per malai. Jumlah malai dan gabah isi menentukan bobot 1000 butir, karena tinggi suhu setiap hari yang berubah selama tahap pematangan menurunkan bobot 1000 butir dan efisiensi pengisian gabah (Oldeman et al., 1986).

Topografi B (Kecamatan Cugenang) dan topografi C (Kecamatan Cianjur) tidak berbeda nyata, karena dalam segi teknik irigasi. Kecamatan Cugenang menggunakan teknik tersier dan Kecamatan Cianjur menggunakan irigasi semi teknis, perbedaan segi teknik irigasi namun kedua lokasi Kecamatan tersebut menggunakan sumber air yang sama yaitu air penggunungan Gunung Gede. Hal ini sesuai dengan penelitian Wihardjaka and Abdurachman (2007), bahwa sawah irigasi memiliki cadangan air yang terus menerus, dikarenakan sumber air utama adalah irigasi dan menyebabkan produksi yang lebih besar dibanding sawah tadah hujan. Menurut Wu et al., (2011) menyebutkan, defisit air mengakibatkan penurunan jumlah dan berat biji sehingga memperkecil produksi dan bahkan sumber air dalam cara budidaya seperti nutrien dalam tanah atau penambahan nutrien berupa pupuk dan cara budidaya menjadi faktor besar kecilnya bobot 1000 butir dan menentukan morfologi benih padi Pandanwangi.

Berbeda hal nya faktor yang menyebabkan topografi A dengan topografi D yang tidak berbeda nyata, karena topografi D memiliki suhu yang relatif dingin yaitu sekitar $18^{\circ} \mathrm{C}-25^{\circ} \mathrm{C}$ atau suhu rendah, yang mengakibatkan perkembangan biji tidak sempurna sehingga pada akhirnya menyebabkan penurunan bobot 1000 butir. Hal itu diperkuat oleh Ismail et al., (2003) yang mengungkapkan bahwa suatu varietas yang memiliki satu gen yang sama akan menghasilkan fenotip sesuai dengan kondisi yang dipengaruhi oleh lingkungan.

Setiap posisi malai pasti memiliki bobot 1000 butir yang berbeda karena varietas dan perbedaan suhu setiap lokasi Kecamatan. Peningkatan atau penurunan suhu berpengaruh pada ketinggian tempat dan kelembaban lokasi yang dapat memberikan karakter benih setiap lokasi, penelitian-penelitian sebelumnya yang menyebutkan bahwa cekaman suhu yang tidak tergolong dalam kriteria areal persawahan padi Pandanwangi atau melebihi atau kurang dari $25^{\circ} \mathrm{C}$ hingga $30^{\circ} \mathrm{C}$ dengan ketinggian $450-800 \mathrm{~m} \mathrm{dpl}$, akan menurunkan bobot 1000 butir benih, karena menurut Reynolds et al., (1994) melaporkan bahwa cekaman suhu tinggi atau melebihi suhu diatas $30^{\circ} \mathrm{C}$ dapat 
merusak membran daun sehingga dampak yang ditimbulkan yaitu terganggunya transport asimilat ke bulir. Sejalan dengan penelitian yang dilakukan oleh Dong et al., (2014) yang melaporkan bahwa bobot 1000 butir pada tanaman padi Pandanwangi yang mendapatkan cekaman suhu tinggi akan lebih rendah bila dibandingkan dengan padi Pandawangi yang dibudidayakan pada suhu normal yaitu, $25^{\circ} \mathrm{C}$ hingga $30^{\circ} \mathrm{C}$.

Topografi E menunjukkan hasil bobot 1000 butir benih yang paling rendah, hal ini disebabkan adanya metabolisme sekunder pada tanaman padi Pandanwangi, sejalan dengan penelitian yang dikemukakan oleh Murakami et al., (2006), menyebutkan bahwa peningkatan kadar asam lemak trienoik pada suatu membran pada suatu tanaman dapat meningkatkan toleransi tanaman terhadap cekaman suhu tinggi yaitu lebih dari $25^{\circ}$ C- $30^{\circ} \mathrm{C}$. Ada kaitanya dengan penelitian Mohammed and Tarpley (2010) and Kim et al., (2011), yang menyebutkan pengisian benih dimulai pada ujung malai, jika terjadi cekaman suhu tinggi akan mengakibatkan penundaan pengisian benih, maka partisi assimilat yang seharusnya di translokasikan untuk pengisian benih yang optimal dibagian ujung malai, menjadi terpecah dan sebagian besar ditranslokasikan ke seludang daun serta ke batang.

Maka pengujian bobot 1000 butir pada lokasi Kecamatan Warungkondang,
Kecamatan Cugenang, Kecamatan Cianjur dan Kecamatan Campaka masih memenuhi syarat sesuai dengan deskripsi umum benih padi Pandanwangi karena masuk kriteria yaitu 29,7 gram, sedangkan untuk Kecamatan Mande tidak termasuk katagori kriteria bobot 1000 butir benih padi Pandanwangi karena total hanya 28,2 gram. Karena menurut ISTA (2005) bahwa penetapan bobot 1000 butir, jika kurang dari deskripsi umum maka memiliki ketidaksesuaian dalam kualitas benih varietas tersebut.

\section{Identifikasi Morfologi Benih Padi Pandawangi}

Identifikasi morfologi benih menjadi peran penting untuk mengenal karakteristik benih walaupun benih Pandanwangi ditanam diberbeda lokasi, benih masih dapat dikenal melalui morfologi dengan kualitas benih yang tetap terjaga salah satunya kemurnian benih dan bobot 1000 butir benih dalam hasil yang memenuhi deskripsi umum tanaman tersebut.

Data hasil penelitian identifikasi morfologi benih padi varietas Pandanwangi di lima lokasi Kecamatan, yang dibandingkan dengan deskripsi umum (Daradjat et al., 2006). Identifikasi morfologi benih padi varietas Pandanwangi secara umum, yaitu pada tabel

Tabel 7. Hasil perbandingan hasil identifikasi morfologi benih padi Pandanwangi di lima lokasi Kecamatan dengan deskripsi umum benih Pandanwnagi.

\begin{tabular}{|c|c|c|c|c|c|c|c|}
\hline \multirow[t]{2}{*}{ No } & \multirow[t]{2}{*}{ Parameter } & \multirow{2}{*}{$\begin{array}{l}\text { Deskripsi } \\
\text { Umum }\end{array}$} & \multicolumn{5}{|c|}{ Lokasi tanam padi sawah varietas Pandanwangi } \\
\hline & & & Warungkondang & Cugenang & Cianjur & Campaka & Mande \\
\hline 1 & $\begin{array}{l}\text { Dominan benih } \\
\text { yang dihasilkan }\end{array}$ & $\begin{array}{c}\text { Bagaimana } \\
\text { perlakuan }\end{array}$ & Besar & Besar & Sedang & Kecil & Sedang \\
\hline 2 & Bulu pada gabah & Berbulu penuh & $\sqrt{ }$ & $\sqrt{ }$ & $\sqrt{ }$ & $\sqrt{ }$ & $\sqrt{ }$ \\
\hline 3 & $\begin{array}{l}\text { Ukuran bulu } \\
\text { gabah }\end{array}$ & Panjang & $\sqrt{ }$ & $\sqrt{ }$ & Pendek & $\sqrt{ }$ & $\sqrt{ }$ \\
\hline 4 & $\begin{array}{l}\text { Wama ujung } \\
\text { gabah }\end{array}$ & Wama jerami & $\sqrt{ }$ & $\sqrt{ }$ & $\sqrt{ }$ & Keemasan & $\begin{array}{c}\text { Tidak } \\
\text { berwama }\end{array}$ \\
\hline 5 & Wama sterilima & Tidak berwama & Wama Jerami & $\sqrt{ }$ & $\sqrt{ }$ & Wama jerami & Wama jerami \\
\hline 6 & Wama gabah & Kuning emas & $\sqrt{ }$ & $\begin{array}{c}\text { Ada galer coklat } \\
\text { pada dasar } \\
\text { wama jerami }\end{array}$ & $\sqrt{ }$ & $\sqrt{ }$ & Wama jerami \\
\hline 7 & Bentuk gabah & $\begin{array}{c}\text { Bulat agak } \\
\text { panjang }\end{array}$ & $\sqrt{ }$ & $\sqrt{ }$ & $\begin{array}{c}\text { Bulat } \\
\text { gemuk }\end{array}$ & Bulat gemuk & $\begin{array}{l}\text { Ramping } \\
\text { panjang }\end{array}$ \\
\hline 9 & $\begin{array}{l}\text { Tipe endosperm } \\
\text { Aroma beras }\end{array}$ & $\begin{array}{l}\text { Berperut } \\
\text { Beraroma } \\
\text { pandan }\end{array}$ & $\sqrt{ }$ & $\sqrt{ }$ & $\sqrt{ }$ & $\sqrt{ }$ & $\begin{array}{c}\text { Beraroma } \\
\text { namun tidak } \\
\text { pekat }\end{array}$ \\
\hline
\end{tabular}


Bahwa identifikasi morfologi benih padi Pandanwangi di lima lokasi kecamatan memiliki karakteristik yang khas. Kesesuian benih padi varietas Pandanwangi di setiap lokasi dibandingkan dengan parameter morfologi benih deskripsi secara umum. Parameter yang diukur pada segi dominan yang dihasilkan setiap lokasi berbeda-beda karena dilihat dari bagaimana tanaman diberi perlakuan secara lingkungan dan manusia. Yang dimaksud perlakuan lingkungan seperti ketinggian tempat, kemiringan lahan, jenis tanah, kelembaban, udara, suhu dan curah hujan.
Sedangkan perlakuan manusia adalah cara budidaya seperti pupuk, pestisida, sumber air yang digunakan oleh para petani dan cara pengelolaannya organik, semi organik atau non organik.

Pada tabel 7. Hasil yang paling baik di lima lokasi Kecamatan adalah Kecamatan Warungkondang dan Kecamatan Cugenang yaitu menghasilkan dominan hasil benih berukuran besar, menurut Ishii (1995) menyatakan suatu varietas tidak hanya ditentukan oleh ukurannya, tapi juga oleh kandungan pati di dalamnya.

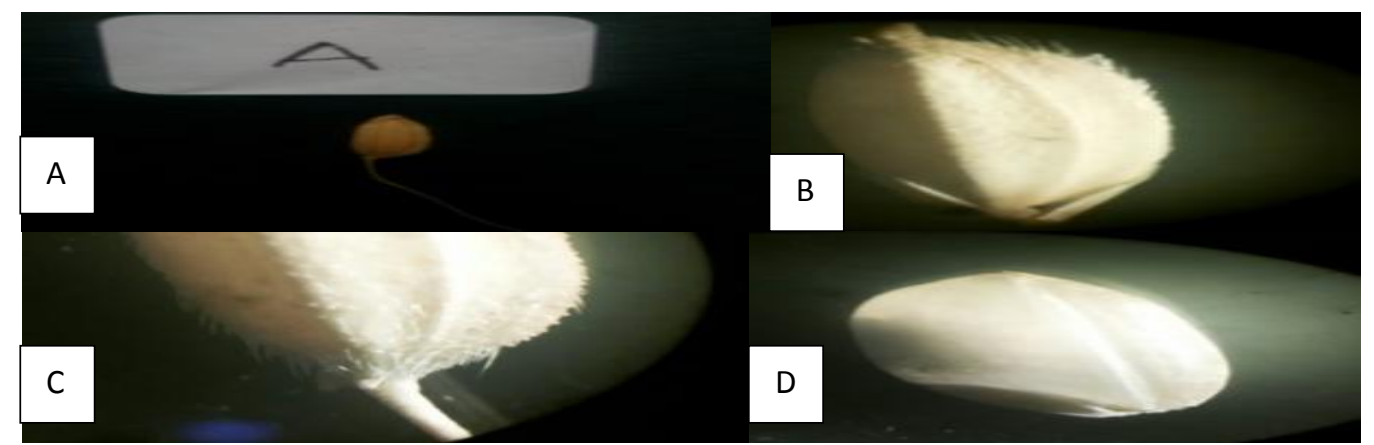

Gambar 3. Morfologi benih lokasi Kecamatan Warungkondang.

Keterangan: $\mathrm{A}=$ Morfologi benih secara keseluruhan, $\mathrm{B}=$ Benih, $\mathrm{C}=$ Ekor benih, $\mathrm{D}=$ Beras .

Tabel 8. Hasil identifikasi morfologi benih padi Pandanwangi di Kecamatan Warungkondang.

\begin{tabular}{|c|c|c|c|}
\hline No & $\begin{array}{r}\text { Ciri-cirimorfologibe } \\
\text { vyarum }\end{array}$ & $\begin{array}{l}\text { padi Pandanvangi di } \\
\text { ndang }\end{array}$ & Keterangan \\
\hline 1 & Bulu pada gabah & Berbulu penuh & Sesuai \\
\hline 2 & Ukuran bulu gabah & Panjang & Sesuai \\
\hline 3 & Wama ujung gabah & Wama Jerami & Sesuai \\
\hline 4 & Wama sterilima & Wama Jerami & Tidak Sesuai \\
\hline 5 & Wama gabah & Keemasan & Sesuai \\
\hline 6 & Bentuk gabah & Bulat agak panjang & Sesuai \\
\hline 7 & Tipe endosperm & Berperut & Sesuai \\
\hline 8 & Aroma beras & Beraroma & Sesuai \\
\hline
\end{tabular}

Parameter untuk deskripsi umum benih padi varietas Pandanwangi menunujukan yang paling banyak kesesuaian berada pada lokasi Kecamatan Warungkondang dan Kecamatan Cugenang, hanya ada satu ketidaksesuaian benih di Kecamatan Warungkondang yaitu warna sterilima yang berwarna jerami berkaitan erat dengan fase bunga yang siap dalam fase perkawinan sesuai dengan penelitian terdahulu yang menyatakan warna benih termasuk bagiannya dikendalikan oleh gen aditif yang beinterkasi dengan dominan (Shimono et al., 2007) dan menurut AKK (1990) bahwa, pembentukan anakan dan warna gabah dan sterilima yang dipengaruhi oleh beberapa faktor, di antaranya adalah umur padi di pesemaian, jarak tanam, musim tanam, serta pemupukan yang sesuai dan termasuk kriteria lingkungan tersebut. 


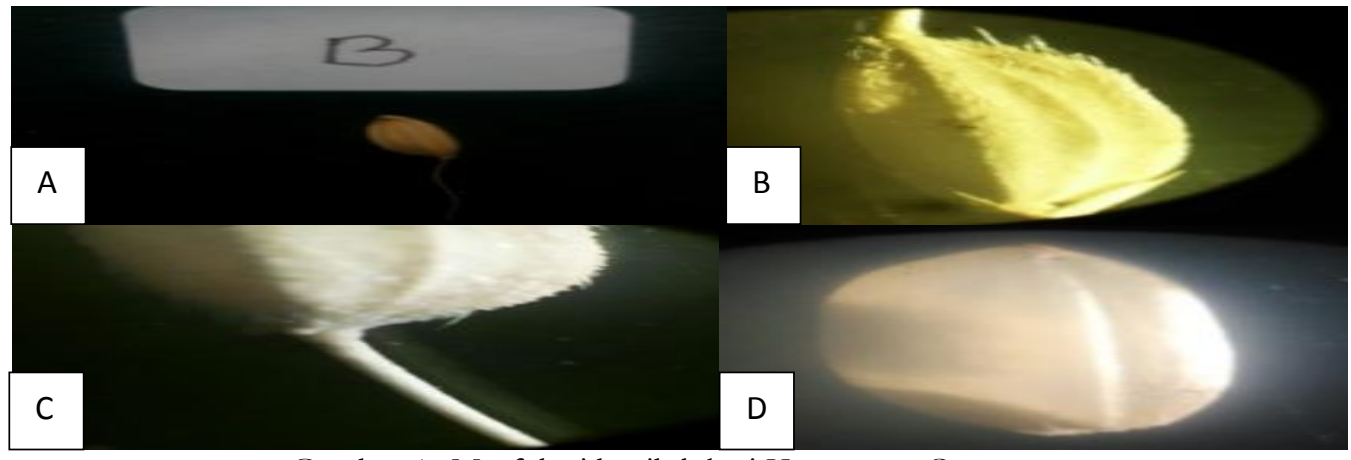

Gambar 4. Morfologi benih lokasi Kecamatan Cugenang.

Keterangan: $\mathrm{A}=$ Morfologi benih secara keseluruhan, $\mathrm{B}=\mathrm{Benih}, \mathrm{C}=$ Ekor benih, $\mathrm{D}=\mathrm{Beras}$

Tabel 9. Hasil identifikasi morfologi benih padi Pandanwangi di Kecamatan Cugenang.

\begin{tabular}{|c|c|c|c|}
\hline No & Ciri-ciri morfologi & $\begin{array}{l}\text { padi Pandanvvangi di } \\
\text { ing }\end{array}$ & Keterangan \\
\hline 1 & Bulu pada gabah & Berbulu penuh & Sesuai \\
\hline 2 & Ukuran bulu gabah & Panjang & Sesuai \\
\hline 3 & Wama ujung gabah & Wama jerami & Sesuai \\
\hline 4 & Wama sterilima & Tidak berwama & Sesuai \\
\hline 5 & Wama gabah & $\begin{array}{c}\text { Ada galer coklat pada } \\
\text { dasar warma jerami }\end{array}$ & Tidak sesuai \\
\hline 6 & Bentuk gabah & Bulat agak panjang & Sesuai \\
\hline 7 & Tipe endosperm & Berperut & Sesuai \\
\hline 8 & Aroma beras & Beraroma & Sesuai \\
\hline
\end{tabular}

Sedangkan pada Kecamatan Cugenang ketidaksesuaiannya pada parameter warna benih yang menunjukkan ada galer coklat pada dasar warna jerami. Artinya adanya ekspresi gen, jika dikaitkan dengan interaksi dengan topografi daerah tersebut. Berdasarkan penelitian Malia (2007), karakter pada benih yang meliputi bentuk, ukuran, permukaan, dan kerontokan dapat digunakan untuk membedakan antar kultivar padi lokal yang ditanam berbeda lokasi. Sementara itu menurut Lesmana et al., (2004), karakter pada gabah yang bisa digunakan untuk membedakan lokasi penanaman padi unggul yang memberikan ciri khas melalui bentuk, warna, dan kerontokan gabah.

Untuk Kecamatan Cianjur memiliki ketidaksesuaian yang tertera pada gambar 5. dengan parameter bulu benih Pandanwangi yang tertera di tabel 10 . yang memiliki ukuran pendek dan bentuk benih yang berbentuk bulat dan gemuk, penyebab yang membedakan panjang atau pendeknya bulu pada benih karena faktor dominan gen yang berinterkasi dengan lingkungan menunjukkan hasil yang tidak menghasilkan dominan gen bulu gabah yang panjang.

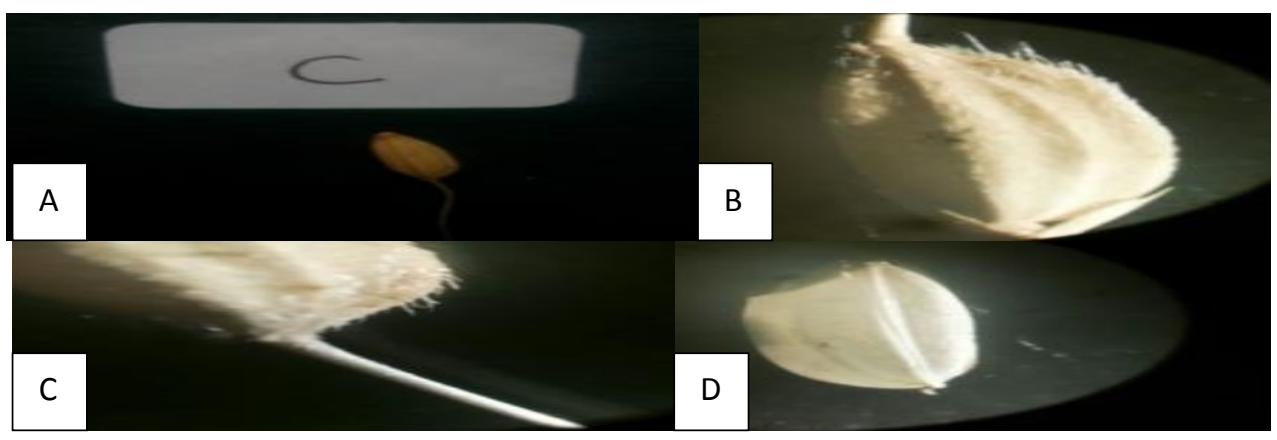

Gambar 5. Morfologi benih lokasi Kecamatan Cianjur

Keterangan: $\mathrm{A}=$ Morfologi benih secara keseluruhan, $\mathrm{B}=$ Benih, $\mathrm{C}=$ Ekor benih, $\mathrm{D}=$ Beras 
Tabel 10. Hasil identifikasi morfologi benih padi Pandanwangi di Kecamatan Cianjur.

\begin{tabular}{cccc}
\hline No & Ciri-ciri morfologi benih padi Pandanvangi di & Keterangan \\
Cianjur & & Sesuai \\
\hline 1 & Bulu pada gabah & Berbuluperuh & Tidak Sesuai \\
2 & Ukuran buu gabah & Pendek & Sesuai \\
3 & Wama ujung gabah & Tidak bervama & Sesuai \\
4 & Wama sterilima & Keemasan & Sesuai \\
5 & Wama gabah & Bulat germuk & Tidak Sesuai \\
6 & Bertuk gabah & Berperut & Sesuai \\
7 & Tipe endosperm & Beraroma & Sesuai \\
8 & Aroma beras & &
\end{tabular}

Sesuai dengan penelitian Shimono et al., (2007), yang menyatakan bahwa panjang bulu, dan persentase gabah bernas dikendalikan oleh gen additif dominan. Bentuk gabah yang bulat gemuk bisa karena isi pati yang banyak didalam gabah, karena ukuran atau bentuk bukan karena ukuran saja tetapi kandungan pati, berdasarkan pernyataan Ishii ( 1995), bahwa produksi pati pada suatu tanaman sangat dipengaruhi oleh sifat genetik tanaman tersebut karena terkait dengan keberadaan dan level ekspresi gen-gen yang terkait dalam proses biosintesisnya cenderung terlihat pada bentuk benih, dan salah satu penelitian oleh Lisle et al.,(2000) yang menyatakan bagian mengapur saat produksi pati atau bagian yang mengapur, terbentuk karena kondisi iklim yang berubah seperti suhu yang tinggi saat fase pengisian benih. Suhu tinggi pada fase stadia pengisian benih akan mempercepat pengisian cairan pati akibatnya terbentuk ruang-ruang udara di antara granula pati di dalam endosperm (Umemoto et al., 1995).

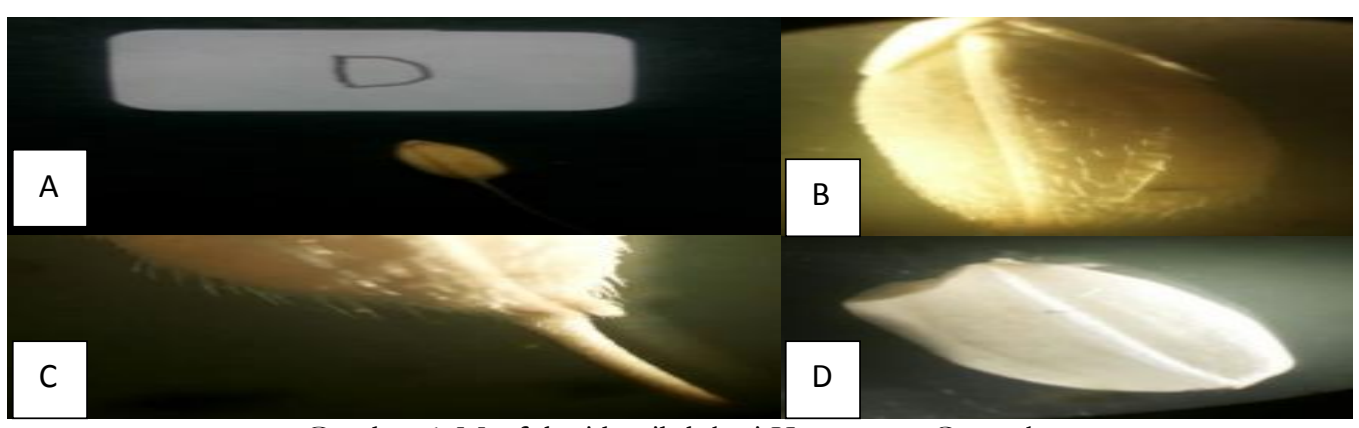

Gambar 6. Morfologi benih lokasi Kecamatan Campaka

Keterangan: $A=$ Morfologi benih secara keseluruhan, $B=$ Benih, $C=$ Ekor benih, $D=$ Beras.

Tabel 11. Hasil identifikasi morfologi benih padi Pandanwangi di Kecamatan Campaka.

\begin{tabular}{cccc}
\hline No & Ciri-ciri morfologi benih padi Pandanvangi di & Keterangan \\
Kecamatan Campaka & Sesuai \\
\hline 1 & Bulu pada gabah & Berbul penuh & Sesuai \\
2 & Ukuran bul gabah & Panjang & Tidak Sesuai \\
3 & Wama ujung gabah & Keemasan & Tidak Sesuai \\
4 & Wama sterilima & Wama jerami & Sesuai \\
5 & Wama gabah & Keemasan & Tidak Sesuai \\
6 & Bentuk gabah & Bulat gemuk & Sesuai \\
7 & Tipe endosperm & Berperut & Sesuai \\
8 & Aroma beras & Beraroma &
\end{tabular}

Di lokasi Kecamatan Campaka memiliki tiga parameter yang berbeda dengan deskripsi umum benih Padi Pandanwangi yaitu warna ujung benih, warna sterilima dan bentuk gabah yang sama dengan Kecamatan Cianjur, karena penyinaran cahaya yang berbeda tiap lokasi bahkan nutrisi yang diberikan akan mempengaruhi warna dan bentuk gabah. Hal ini sesuai dengan penelitian Ishii (1995), yang menyatakan bahwa penyinaran yang berbeda pada setiap sudut, dengan penyinaran maka tingkat fotosintesis yang yang dipengaruhi oleh intensitas cahaya yang optimum pada pertanaman yang ditunjang oleh 
ketersediaan air yang mencukupi di lahan sawah menghasilkan asimilat yang cukup untuk pengisian biji yang mempengaruhi warna dan bentuk.

Untuk lokasi Kecamatan Mande memiliki ketidaksesuaian yang paling banyak dengan terlihat pada gambar 7 . dan deskripsi umum benih padi varietas Pandanwangi, yaitu dari beberapa parameter yang ada pada tabel 12. terlihat perbedaan warna ujung benih, warna sterilima, bentuk benih yang ramping dan panjang dan aroma beras yang tidak pekat. Hal ini karena beberapa faktor, yaitu keterkaitannya antarahasil ekspresi gen yang berinteraksi dengan lingkungan lokasi Kecamatan Mande yang tidak memenuhi kriteria tanaman padi Pandanwangi. Lingkungan dilokasi Kecamatan Mande memberikan hasil yang berbeda dengan deskripsi umum morfologi benih Pandanwangi secara umum. Karena berdasarkan penelitian bahwa keragaman penampilan tanaman akibat perbedaan susunan genetik selalu mungkin terjadi sekalipun bahan tanaman yang digunakan berasal dari jenis tanaman yang sama, karena pembuktinya lingkungan yang berbeda akan menghasilkan gen yang berbeda (Sitompil and Guritno, 1995).

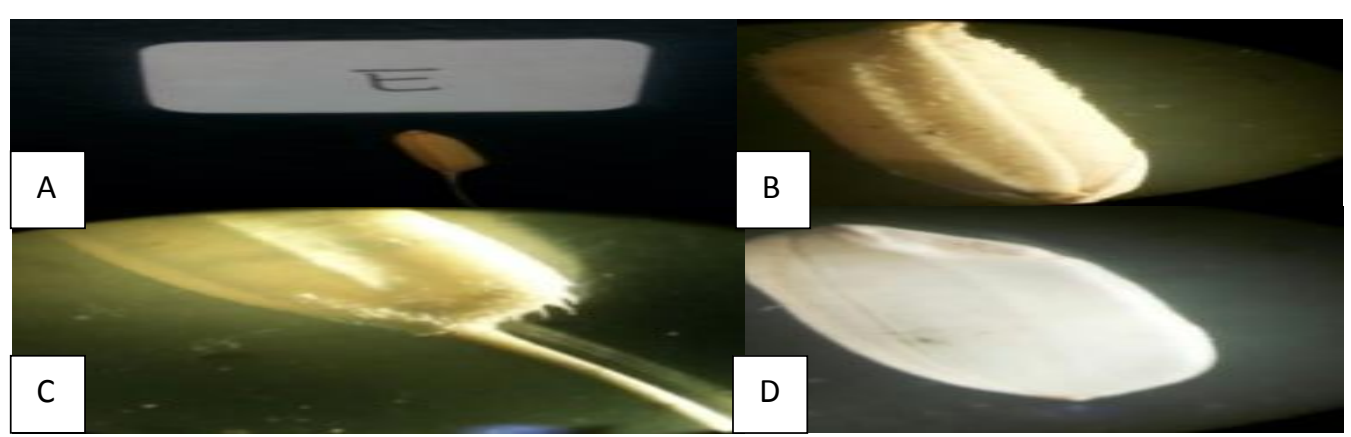

Gambar 7. Morfologi benih lokasi Kecamatan Mande.

Keterangan: $\mathrm{A}=$ Morfologi benih secara keseluruhan, $\mathrm{B}=$ Benih, $\mathrm{C}=$ Ekor benih, $\mathrm{D}=$ Beras.

Tabel 12. Hasil identifikasi morfologi benih padi Pandanwangi di Kecamatan Mande.

\begin{tabular}{cccc}
\hline No & Ciri-ciri morfologi benih padi Pandanvangi di & Keterangan \\
Kecamatan Mande & Berbulu peruh & Sesuai \\
\hline 1 & Bulu pada gabah & Panjang & Tidak Sesuai \\
2 & Ukuran bulu gabah & Tidak berwarna & Tidak Sesuai \\
3 & Wama ujung gabah & Wama jerami & Tidak Sesuai \\
4 & Wama sterilima & Wama jerami & Tidak Sesuai \\
5 & Wama gabah & Ramping panjang & Sesuai \\
6 & Bentuk gabah & Berperut & Tidak Sesuai \\
7 & Tipe endosperm & Beraoma namun tidak & pekat \\
8 & Aroma beras & &
\end{tabular}

30 Bahkan aroma yang telah diuji oleh menghasilkan aroma Pandanwangi namun tidak pekat karena bisa terjadi karena penangan pascapanen, hal ini sesuai dengan pendapat Cagampang et al., (1973), bahwa perbedaan konsentrasi dan jenis aroma yang terkandung pada masing-masing varietas terutama disebabkan oleh faktor genetis, selain juga karena kondisi tempat tumbuh dan penanganan pascapanen dan kandungan senyawa 2-Acetyl-1-pyrroline pada beras aromatik 15 kali lebih tinggi dibanding pada beras non aromatik (Weber et al., 2000).

Selain dari aroma yang menjadi ciri khas Pandanwangi adalah benih yang memiliki ekor, dari lima lokasi Kecamatan teidentifikasi setiap benih Pandanwangi memiliki ekor, hal ini disebabkan jenis padi Pandanwangi adalah Javanica sesuai dengan penelitian Irawan and Purbayanti (2008), menyatakan pada karakter tipe permukaan benih, dilihat dari perbedaan karakteristik padi indica dan javanica salah satunya adalah pada ada atau tidaknya ekor/bulu pada ujung benih, padi indica 
tidak memiliki ekor/bulu, sementara padi javanica memiliki ekor/bulu benih.

Perbedaan karakteristik setiap lokasi dikarenakan perlakuan manusia dan lingkungan dan menurut Allard (1960) mengungkapkan hal yang sama bahwa, lingkungan yang mempengaruhi hasil didukung juga oleh perlakuan manusia, sehingga setiap tempat tumbuh bervariasi memberikan hasil sesuai pengaruh lingkungan dan manusia dan Zen and Syarif (2013) pun mengungkapkan meskipun padi Pandanwangi memiliki umur yang relatif panjang, petani masih membudidayakan varietas tersebut karena telah beradaptasi dengan lokasi spesifik atau kriteria Pandanwangi yang memiliki kualitas dan kuantitas yang baik secara turun temurun.

Karakteristik benih padi Pandawangi yang sudah diteliti akan menjadi cerminan perlakuan yang diberikan pada hasil akhir yaitu benih yang nantinya akan diolah menjadi benih unggulan tanpa menghilangkan kualitas benih tersebut, yang dimaksud dari karakteristik benih padi Pandawangi yang sudah diteliti akan menjadi cerminan perlakuan yang diberikan pada tanaman padi varietas Pandanwangi yaitu, karena menurut survei setiap lokasi perlakuan alami dan manusia berbeda. Lingkungan akan berpengaruh terhadapkarakter varietas padi Pandanwangi dan dapat disebut memasuki kriteria deskripsi umum morfologi benih yaitu tumbuh baik di wilayah penyebaran tanpa menghilangkan ciri khas (Somartono et al., 2006).

Perlakuan manusia seperti budidaya padi varietas Pandanwangi di lokasi Kecamatan Warungkondang dan Kecamatan Campaka, mengelola dengan budidaya semi organik sedangkan pengelolaan Kecamatan Cugenang dan Kecamatan Cianjur dikelola secara organik. Beda hal nya dengan Kecamatan Mande yang dikelola secara non organik karena menurut Pramono (2004) intensifikasi padi dengan asupan pupuk kimia dalam jumlah besar dan dalam jangka waktu lama, serta penggunaan bahan organik dalam sistem produksi padi sawah Pandanwangi mengakibatkan terganggunya keseimbangan hara tanah yang berakibat terhadap penurunan kualitas hasil. Hal ini dibenarkan karena hasil pengujian kemurnian benih dan penetapan bobot 1000 butir yang terendah dari lima lokasi Kecamatan dan morfologi benih paling banyak ketidaksesuaiannya.

Pengelolaan yang berbeda maka penggunaan pupuk dan pestisida yang digunakan setiap lokasi Kecamatan akan berbeda. Sumber air yang sama untuk empat lokasi Kecamatan, sedangkan Kecamatan Mande menggunakan tadah hujan dan irigasi tersier, teknik irigasi tersier pun digunakan di Kecamatan Warungkondang dan Kecamatan Campaka. Untuk Kecamatan Cugenang dan Kecamatan Cianjur menggunakan Irigasi semi teknis.

Identifikasi morfologi benih padi varietas Pandawangi dibandingkan dengan hasil pengujian mutu fisik yaitu pengujian kumurnian benih dan penetapan bobot 1000 butir setiap lokasi, ternyata benar perlakuan alami dan manusia berpengaruh terhadap morfologi benih dan kualitas mutu fisik benih sesuai dengan penelitian Mangoendidjojo (2000) penampilan suatu tanaman dan hasilnya pada suatu lingkungan tumbuhnya merupakan dampak kerja sama antara faktor genetik dengan lingkungan. Penampilan suatu genotip pada lingkunganyang berbeda dapat berbeda juga, sehingga sampai seberapa jauh interaksi antara genotip dan lingkungan $(G \times E)$ merupakan suatu hal yang sangat penting untuk diketahui dalam program pemuliaan ataupun dalam rangka pengembangan padi Pandanwangi untuk varietas lokal Kabupaten Cianjur. Salah satu upaya agar meningkatkan produktivitas dan menciptapkan kualitas yang terbaik untuk padi Pandanwangi adalah dengan mencipta kan lingkungan tumbuh yang optimal untuk setiap fase pertumbuhan dan perkembangan tanaman (Djoyowasisto et al., 2007). 


\section{KESIMPULAN}

Berdasarkan hasil penelitian identifikasi morfologi benih di lima lokasi Kecamatan dapat disimpulkan bahwa secara umum karakteristik morfologi benih pada empat lokasi Kecamatan yaitu Kecamatan Warungkondang, Kecamatan Cugenang, Kecamatan Cianjur dan Kecamatan Campaka menunjukkan perbedaan karakteristik namun masih masuk ke dalam karakteristik secara umum morfologi benih padi Pandanwangi sebagai acuan pembanding. Sedangkan untuk Kecamatan Mande merupakan lokasi yang menunjukkan karakteristik morfologi benih padi Pandanwangi yang ketidaksesuaiannya yang paling banyak setelah dibandingkan dengan deskripsi umum morfologi benih padi Pandanwangi.

Topografi yang berbeda dari lima lokasi Kecamatan, yaitu Kecamatan Warungkondang, Kecamatan Cugenang, Kecamatan Cianjur, Kecamatan Campaka dan Kecamatan Mande berpengaruh terhadap kemurnian benih dan bobot 1000 butir benih padi Pandanwangi. Kecamatan Warungkondang merupakan topografi yang memberikan pengaruh paling baik terhadap pengujian kualitas mutu fisik. Hal ini terbukti bahwa topografi berpengaruh nyata terhadap morfologi benih tiap wilayah yang ditanam padi Pandanwangi.

\section{DAFTAR PUSTAKA}

Aksi Agraris Kanisius. 1990. Budidaya Tanaman Padi. Yogyakarta : Kanisius.

Agrios, G.N. 2005. Plant Pathology. Fifth Edition. New York : Elsevier Academic Press.

Allard, R.W. 1960. Dasar-dasar Pemuliaan Tanaman. Terjemahan Manna dan Mul Mulyani. Jakarta: Rieka Bina Aksara.

Balai Penelitian Tanaman Padi. 2004. Laporan Hasil Validasi Tugas Akbir 2004. Jakarta.
Balai Pengembangan Mutu Benih Tanaman Pangan dan Hortikultura. 2004. Laporan Hasil Validas Tugas Akbir 2004. Jakarta.

Cagampang, Gloria B, C.M. Perez, and B.O. Juliano. 1973. A Gel Consistency Test for Eating Quality of Rice. Journal of the Science of Food and Agriculture. 24(12): 15891594.

Charomaini, Sri Rukun and Diana Windiasih. 2005. Hubungan Benih Dengan Patogen Sebagai Penyebar Penyakit. Jurnal Penelitian Hutan Tanaman. 2 (2): 68-73

Daradjat, A.A., S. Wahyuni, and Nafisah. 2006. Interaksi genotipe lingkungan dan analisis keterulangan karakter ukuran gabah varietas unggul padi. Risalah Seminar 2005. Pusat Penelitian dan Pengembangan Tanaman Pangan. Bogor. 2 (2) : 67-79.

Djoyowasito, G. Ekoyanto. P and G. Maides. 2007. Mempelajari kinerja Pita tanam organik pada pertumbuhan dan produksi tanaman padi sawah (Oryza sativa L). Jurusan Teknologi Pertanian Univesitas Brawijaya Malang. 10(3) : 200-204.

Dong W, Chen J, Wang L, Tian Y, Zhang B, Lai Y, Meng Y, Qian C, Guo J. 2014. Impacts of Nighttime PostAnthesis Warming On Rice Productivity And Grain Quality In East China. The Crop Journal. 2: 6369.

Imran, S., Syamsuddin, and Efendi. 2002. Analisis vigor benih padi (Oryza sativa L.) pada lahan alang-alang. Agrista Fakultas Pertanian Universitas Syiah Kuala. 6(1): 81-86.

International Rules for Seed Testing. 2006. The International Seed Testing Association (ISTA): Edition 2006. Switzerland: Bassersdorf CH-8303.

Irawan B, Purbayanti K. 2008. Karakterisasi dan kekerabatan kultivar padi lokal di Desa Rancakalong, Kecamatan Rancakalong, Kabupaten 
Sumedang. Agrikultulra. Sumedang. pp. 21-23.

Ishii, R. 1995. Effect of physiological factors on individual leaves on photosynthesis and respiration. In Matsuo, T., Kumazawa, K., Ishii, R., Ishii, K. and Hirata, H. (Eds.). Science of the Rice Plant. Physiology. Food and Agriculture Policy Research Centre, Tokyo. pp. 2 (1): 566-596.

Ismail, B.P., Suprihatno, H Pane and I. Las. 2003. Pemanfaatan penciri abiotik lingkungan tumbuh dalam seleksi simultan galur padi gogorancah toleran kekeringan. Pusat Penelitian dan Pengembangan Tanaman Pangan Bogor dalam Makarim, A. K, and Ikhwani, Respon Komponen Hasil Varietas Padi Terhadap Perlakuan Agronomi. Jurnal Penelitian Pertanian Tanaman. 27(1): 33-34.

J. D. Bewley, K. Bradford, H. Hilhorst and H. Nonogaki. 2012. Seeds: physiology of development, germination and dormancy. Springer Science \& Business Media. 2 (72): 227 261.

Kim J, Shon J, Lee C. K., Yang W, Yoon W, Yang W. H., Kim Y.G, Lee B.W. 2011. Relationship between grain filling duration and leaf senescence of temperate rice under high temperature. Field Crops Res. 2 (122): 207-213.

Lesmana O.S, Toha H.M, Las I, Suprihatno B. 2004. Deskripsi varietas unggul baru padi. Subang: Balai Besar Padi Sukamandi

Lisle, A. J., M. Martin, and M. A., Fitzgerald. 2002. Chalky and translucent rice grains differ in starch composition and structure and cooking properties. Cereal Chemistry. 77: 627-260.

Malia R. 2007. Studi Pemanfaatan dan pengelolaan kultivar padi lokal di Desa Rancakalong, Kabupaten Sumedang, Jawa Barat. [Skripsi]. Jurusan Biologi, FMIPA Unpad, Jatinangor.
Mangoendidjojo, W. 2002. Analisis Interaksi Genotip Lingkungan Tanaman Perkebunan. Zuriat. 11(1): 21-27.

Masyarakat Pelestari Padi Pandanwangi Cianjur. 2015. Buku Persyaratan Permohonan Pendaftaran Indikasi Geografis Beras Pandanwangi Cianjur. Cianjur.

Mohammed A.R, Tarpley R. 2010. Effects of high night temperature and spikelet position on yield-related parameters of rice (Oryza sativa L.) plants. Europ Journal Agronomy. 33: 117-123.

Mulsanti, I.W., M. Surahman, S. Wahyuni, D.W. Utami. 2013. Identifikasi galur tetua padi hibrida dengan marka SSR spesifik dan pemanfaatannya dalam uji kemurnian benih. Jurnal Penelitian Pertanian Tanaman Pangan. 32(1): 1-8.

Murakami Y, Tsuyama M, Kobayashi Y, Kodama H, Iba K. 2006. Trienoic fatty acids and plant tolerance of high temperature. Science. 5452(287): $476-479$.

Nagai D, Makino A. 2009. Differences between rice and wheat in temperature responses of photosynthesis and plant growth. Plant Cell Physiol. 50(4): 744-755.

Natalia, L. 2006. Pengendalian Penyakit Antraks: Diagnosis, Vaksinasi dan Investigasi. Wartazoa.16 (4): 198205.

Nurjannah, E.E, Irwan.Y, Helvi. 2013. Analisis Komponen Utama FaktorFaktor Yang Mempengaruhi Keputusan Petani Menggunakan Benih Padi Inhibridadi Kabupaten Lampung Tengah. Jurnal Ilmu-Ilmu Agribisnis. 1(2): 40-41.

Oldeman L.R., Shesu D.V, Cady F.B. 1986. Response of rice to weather variables. Manila $(\mathrm{PH})$ : IRRI.

Pramono. J. 2004. Kajian penggunaan bahan organik pada padi sawah. Agrosains. 6(1):11-14.

Reynolds M.P, Balota M, Delgado M.I.B, Aman I, Fisher R.A. 1994. 
Physiological and morphological traits associated with spring wheat yield under hot irrigated conditions. Plant Physiol. 21(1): 717-730.

Shimono, K.M. Okada, E. Kanda, I. Arakawa. 2007. Low temperatureinduced sterility in rice: Evidence for the effects of temperature before panicle initiation. Field Crops Res. 101(5): 221-231.

Sitaresmi, T.N. Yunani, K.A.F. Zakki, I.W. Mulsanti, S.T. Utomo, and A.A. Daradjat, 2013.Identifikasi varietas contoh untuk karakter penciri spesifik sebagai penunjang harmonisasi pengujian BUSS padi. Jurnal Penelitian Pertanian Tanaman Pangan. 32(3): 148.

Sitompul, S.M, and B. Guritno. 1995. Analisis Pertumbuhan Tanaman. Yogyakarta: Gadjah Mada University Press.

Suena, 2009. Pedoman Umum Analisis Mutu Benih. Direktorat Jenderal Pertanian Tanaman Pangan dan Hortikultura. Jakarta: Direktorat Bina.

Sukarman and M Hasanah. 2005. Perbaikan mutu Benih Aneka Tanaman Perkebunan Melalui Cara Panen dan Penangan Benih. Jurnal Litbang Pertanian. 22(1): 16-23.

Sumartono. B. Samad and R. Hardjono. 2006. Bercocok Tanam Padi. Cetakan 12. CV. Jakarta: Yasaguna.

Toriyama, K. 1994. Studies on estimation of nitrogen mineralization pattern of lowland rice field and nitrogen fertilizing model for rice plant. Res. Bull. Hokuriku Nat. (In Japanese, with English abstract.) Agriculture. Experiment. Stn. 36: 147-198.

Wahyuni, S., U.S. Nugraha, and Triny S. Kadir. 2004. Viabilitas dan vigor benih dari beberapa varietas dan berat jenis serta pengaruhnya terhadap pertumbuhan dan mutu benih. Prosiding Lokakarya Perhimpunan Ilmu Pemuliaan Indonesia VII. Kerja sama PERIPI dengan BALITKABI. pp: 302-311.
Wahyuni, S., Nugraha, U.S. and Kadir, T.S. 2005. Evaluasi teknik pengelolaan dan mutu benih padi gogo di tingkat petani. Jurnal Ilmu Pertanian Indonesia. 8 (1): 1-5.

Weber, D.J. Rohilla, R., Khush, G.S. 2000. Aromatic Rices. New Delhi: Calcutta Oxford \& IBH Publishing Co. Pvt. Ltd.

Wihardjaka A, Abdurachman S. 2007. Dampak Pemupukan Jangka Panjang Padi Sawah Tadah Hujan terhadap Emisi Gas Metana. Penelitian Pertanian Tanaman Pangan. 26(1): 1-7

Wu, Paul C.S. 2011. The Effect of Store Image and Service Quality on Brand Image and Purchase Intention for Private Label Brands. Australian Marketing Journal.

Yoshida S, Parao FT. 1976. Climate influence on yield and yield components of lowland rice in tropics. Proccedings of Symposium on Climate and Rice; Los Banos, Philippines. Los Banos (PH): IRRI. 2(1): 471-494.

Zen S, Syarif AA. 2013. Peluang perbaikan varietas lokal padi gogo Pasaman Barat. Buletin Plasma Nutfah. 19 (1): 1-8. 